\title{
ドラム缶式無菌バッグの耐振動衝撃性
}

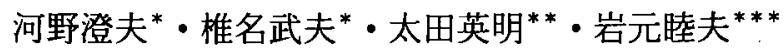

\section{Durability of Bag-in-drum Type of Aseptic Container against \\ Shocks and Vibrations during Transportation}

\author{
Sumio KaWAno*, Takeo ShIInA ${ }^{*}$, Hideaki OHta ${ }^{* *}$ \\ and Mutsuo Iwamoto ${ }^{* * *}$ \\ *National Food Research Institute, Kannondai, Tsukuba 305 \\ ${ }^{* *}$ Chugoku National Agricultural Experiment Station \\ Nishifukatsu, Fukuyama 721 \\ ${ }^{* * *}$ Ministry of Agriculture, Forestry and Fisheries \\ Kasumigaseki, Chiyoda-ku 100
}

The durability of a bag-in-drum type aseptic container was examined during transportation for more than $1200 \mathrm{~km}$; this type of container is becoming popular at present for orange juice or tomato puree. The container received severe damage of cracks and pin-holes. The damage was more serious in case of shipment by train than by truck and ferry boat, because the resonance frequency of the products in the aseptic bag was mostly equivalent to the lowest vibrating frequency of transporting vibration in the train. The damage could be reduced by supporting the aseptic bag in the drum with two semicircular plates of polystyrene foam.

(Received Jun. 14, 1988)

最近, ドラム缶式無菌バッグが果汁の保存, 輸送容器 として用いられ始めている. 果汁は，従来，5〜6倍に 濃縮, 凍結されドラム缶などによって冷涷眝蔵されてき だが，眝蔵コストがかさむことや，特にストレート果 汁の場合, 凍結によって風味が低下することなどから新 しい眝蔵方式の開発が求められてきた。

ドラム缶式無菌バッグは，アルミニウムをラミネート した袋状の無菌充填用包装容器で，液状食品を室温で長 期間保存できる特長をしている.

しかし，バッグインボックス，液状食品用紙容器”之 同様，輸送中の振動衝撃によりクラックやピンホールな どの損傷が生じる危険性がある。このような損傷は，バ ッグ内の無菌状態を破塄するばかりでなく，著しい場合 には果汁自身を污染する恐饥があり，安全性の面から改
善策が求められてきた。

このため，本研究では，同無菌バッグの耐振動衛擊性 について解明するとともに，クラックやピンホールに対 する緩衝包装の改善策について検討した。

\section{実 験 方 法}

\section{1. 供試材料}

Fig. 1 に示すように鉄製のドラム缶に無菌バッグを 入れ，その中に内容物を充填する方式の容器を用いた。 供試したバッグの仕様は Table. 1 のとおりで, 内容物, 容量及び緩衝方式により Table. 2 のように A J の 10 とおりの実験区を設けた。

\section{2. 翰送試呀}

(1) トラックによるモデル走行

\footnotetext{
*農林水産省食品総合研究所（厂305 茨城県つくば市観音台 2-1-2）

**農林水産省中国農業試験場（宁721 広島県福山市西深津町 6-12-1）

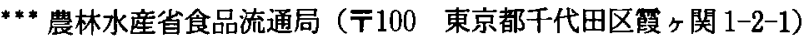




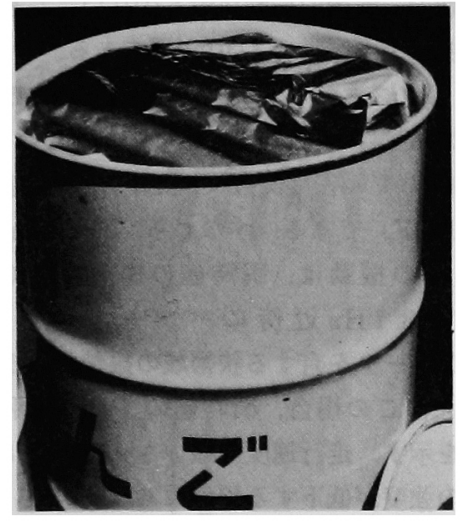

Fig. 1 A bag-in-drum type aseptic container tested

Table 1 Specifications of the aseptic bag

\begin{tabular}{ll}
\hline \hline Structure & NY $\left(17 \mathrm{~g} / \mathrm{m}^{2}\right) / \mathrm{AL}\left(23 \mathrm{~g} / \mathrm{m}^{2}\right)$ \\
& $/ \mathrm{NY}\left(17 \mathrm{~g} / \mathrm{m}^{2}\right) / \mathrm{EVA}\left(20 \mathrm{~g} / \mathrm{m}^{2}\right)$ \\
Size & $191(H) \times 55.5(L) \times 70(W)(\mathrm{cm})$ \\
\hline
\end{tabular}

$2 \mathrm{t}$ 用トラック（いすず，貨物）に，ドラム缶 8 本 （約 $1.6 \mathrm{t}$ ）を積載し，定速走行時に荷台後部に発生する 振動加速度を小型衝撃記録計（吉田精機(株)製，FIR102）及び歪ゲージ式加速計（共和(株)製， AS-5 C）で 測定した，加速度の測定方向は，上下，左右，前後の 3 方向とした、アスファルト舗装の農道を $10 \mathrm{~km} / \mathrm{h}$ の速 度から $10 \mathrm{~km} / \mathrm{h}$ おきに $60 \mathrm{~km} / \mathrm{h}$ の速度まで 6 段階の 速度で定速走行した。

(2) トラック・フェリー翰送

10 tトラック (Fig. 2-(1)) により，48本のドラム 缶を大分県果実連杵築工場（大分県杵築市）加ら西宇和 青果倉庫（神奈川県海老名市）まで輸送した，輸送経路 は, 杵築(トラック)-別府-(フェリー)-大阪-(トラック)(高速)-岡崎-(トラック)-沼津-(トラック)-海老名の順 で，輸送中にトラック後部荷台に発生する前後，左右， 上下の振動加速度を小型衝擊記録計及び歪ゲージ式加速 度計で測定した，航海中のフェリーの振動は，乗船した 甲板上のトラック荷台上で測定した。フェリーは大型外 洋フェリー, サンフラワー2 (関西汽船(株)）(Fig. 2(2)）で, 紷トン数 $12130 \mathrm{t}$, 全長 $185 \mathrm{~m}$, 幅 $24 \mathrm{~m}$ で あった.

(3) 貨車輸送

24 本のドラム缶を $5 \mathrm{t}$ 用コンテナ（Fig. 3）により
Table 2 Summary of samples

\begin{tabular}{cccc}
\hline \hline Samples & Product & Volume $(l)$ & Type of packing* \\
\hline A & Juice & 162 & Method 1 \\
B & Juice & 162 & Method 2 \\
C & Juice & 162 & Method 3 \\
D & Juice & 162 & Method 4 \\
E & Juice & 162 & Frozen in part \\
F & Water & 180 & \\
G & Water & 150 & Method 4 \\
H & Water & 150 & \\
I & Water & 120 & Method 4 \\
J & Water & 120 & \\
\hline
\end{tabular}

* Type of packing

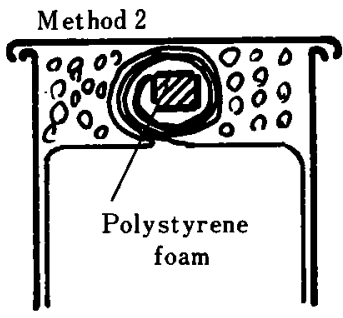

Method 3
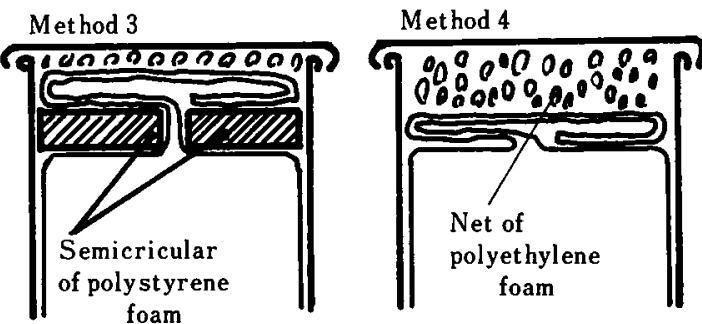

輸送した，輸送経路は，杵築ー(トラック)ー西大分-(貨車)東京-(トラック)-海老名倉庫の順で，輸送中にコンテナ 底面に発生する振動加速度を小型衝撃記録計で測定した。 電気的方法による振動の測定は，コンテナを積載した車 両を連結した列車（コキ55000形式，貨物 17 両編成， 約 $350 \mathrm{~m}$ ) の最後部の車轌 (コキフ)で行い，床に発 生する上下，左右，前後の振動を歪ゲージ式加速度計に より湘定し，データレコーダに収録した．湘定は西大分 駅及び宇島駅間の約 $85 \mathrm{~km}$ の区間で実施した。

3. 加速度の測定及び解析 歪ゲージ式加速度計で検出した振動加速度の電気信号 


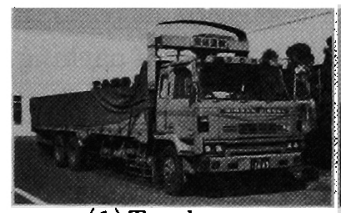

(1) Truck

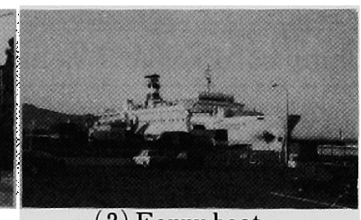

(2) Ferry boat
Fig. 2 A truck and a ferry boat used for transportation

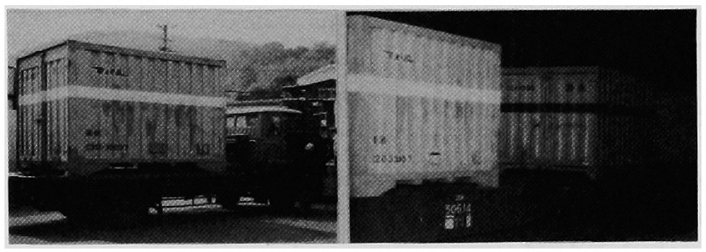

Fig. 3 Shipping container $(5 \mathrm{t})$ used for transportation by train

は，データレコーダ（ティアック製， R-71）に記録 した。、いずれの場合も，シグナルコンディショナ（共 和製，CDV-110 A）を増幅器として用い，同器に内蔵 されたローパスフィル夕（100 Hz 以下パス）を使用 した。記録方式はFM 形式とし，ノイズの影響を除 くため, 再生時にノイズ補償を行う COMP 機能を併用 した.

データレコーダに記録した信号の解析には，リアルタ イム信号解析装置（日本無線製，JEF-12 AJ）を用い, 瞬時値の確率密度関数，パワースペクトル密度関数につ いて解析した。解析時の主な条件は, ブロックサイズ 1024 , サンプリング時間間隔 $10 \mathrm{~ms}$, 平均回数 8 回上 した. また，小型衝撃記録計に記録されたデータの読み 取りにはディジタイザ（ヒューレット・パッカード製, 9874 A）を用いた。

\section{4. 損符程度の判定}

それぞれの方式で輸送したドラム午式無菌バッグの損 傷程度を、クラックとピンホールの観点から, 目視によ り判定した。損傷程度は, (1) 無, (2) 微, (3)中, (4) 甚の 4 段階とし，それぞれに評点 0 ３ を与えた。

\section{実験結果及び考察}

\section{1. モデル走行中のトラック荷台の振動特性}

$2 \mathrm{t} ト$ トック荷台に発生する上下, 左右, 前後の振動 加速度を電気的に測定した.トラックの荷台に発生する 振動は，3方向の中で上下の振動が最む激しく，次いで
左右の振動で, 前後の振動が最む少ない. 左右, 前後の 振動の強度は上下振動の $1 / 10$ 以下である。

Fig. 4 はアスファルト道路を $50 \mathrm{~km} / \mathrm{h}$ で走行中の 上下の振動加速度の解析結果であって, 上段より原信号， パワースペクトル密度関数 (PSDF), 瞬時値の確率密 度関数 (PDF) である。すなわち, $50 \mathrm{~km} / \mathrm{h}$ で走行中 のトラックの振動は, 瞬時值の標準偏差 (STD) が $0.12 \mathrm{G}$ で， $3.1 \mathrm{~Hz}$ 近傍にパワースペクトル密度 (PSD) のピークを有する狭帯域の振動であることがわ かる.また，この場合，瞬時値の PDF は平均値0の 正規分布を示す. 走行速度を減少させると，18〜 $25 \mathrm{~Hz}$ の PSD の強度が低下する傾向にあったが，いずれの速 度む，2 3 Hz 近傍に PSD のピークを有する狭帯域の 振動であった。

\section{2. 各輸送機関に発生する振動}

ドラム缶式無菌バッグ輸送中に各輸送機関に発生する 上下, 左右, 前後の振動加速度のパワースペクトル密度 関数及びパワースペクトル分布関数を Fig. 5 に示す. 図中，(1) は $60 \sim 70 \mathrm{~km} / \mathrm{h}$ で走行中の貨車の床面に，

（2）は $60 \mathrm{~km} / \mathrm{h}$ で走行中のトラック荷台後部に、そし

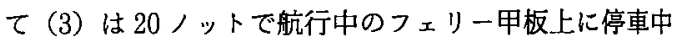
のトラック後部荷台に発生する振動の解析結果である.

解析したパワースペクトル密度関数は，輸送機関及び振 動の方向によって大きく異なった.すなわち，トラック の上下振動は, $3 \mathrm{~Hz}$ の近傍にパワースペクトル密度の ピークを有する狭帯域の振動であるのに対し, 左右の振 動は $1 \mathrm{~Hz}$ 以下と $14 \mathrm{~Hz}$ 近傍でピークを有する広帯域 の振動である. また, 前後振動は, 左右の振動の同様, $1 \mathrm{~Hz}$ 以下の比較的ゆっくりした捡動と $12 \mathrm{~Hz}$ を中心 した広帯域の振動から構成されている.

一方，貨車の上下振動は，トラックの上下振動之同様， 狭帯域の振動であるが，PSDのピーク値を示す振動数 はトラックのそれより低い $2 \mathrm{~Hz}$ 近傍に存在する. また， 左右振動は，1.2，2.8，7.8 Hz の近傍に PSD の極值 を有する広帯域の振動で, トラックの左右振動と異なっ たスペクトルを示す. 貨車の前後振動は， $7 \mathrm{~Hz}$ 近傍に PSD のピークを有するむのの, $20 \mathrm{~Hz}$ 以下のほぼ全振 動数成分を含んだランダムな波形である。

フェリーの甲板上に停車したトラックの振動は，先に 述べた貨車及び国道走行中のトラックの振動と比較して, 非常に小さく，その大きさは $1 / 40$ 程度である.

\section{3. 輸送後の無菌バッグの損甥程度}

輸送後，ドラム缶内の無菌バッグには，Fig. 6 に示 すようなクラックが発生し，著しい場合にはピンホール 


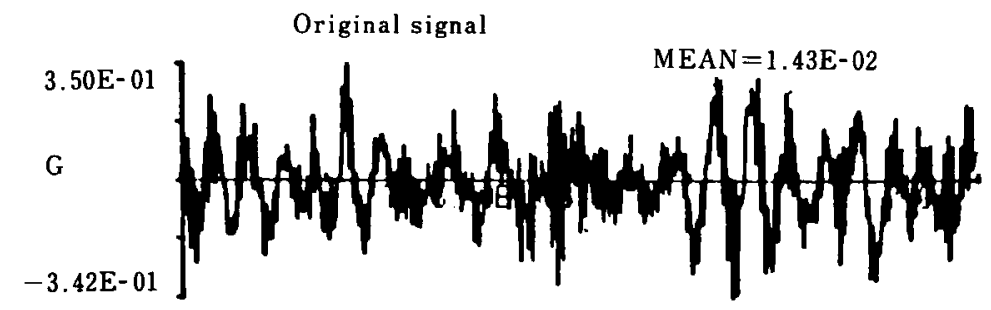

DATE TIME

1985-4-23

EXP NO

1

PHENOMENOH

UP-DOWN

$50 \mathrm{HZ}$ CUT

FILTER

CAL FACTOR

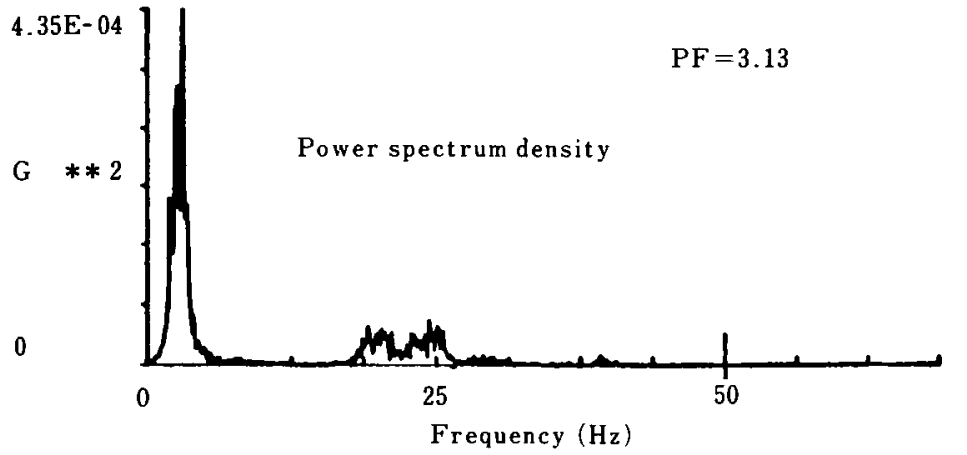

1.63

G / U 01

1.00

G /U 02

NO. OF DATA

8192.00

BLOCK SIZE

1024

NO. OF LAG

$\times 16 * 2$

AVE. TIME

8 (B)

SAMP. TIME

1.00E-02 S

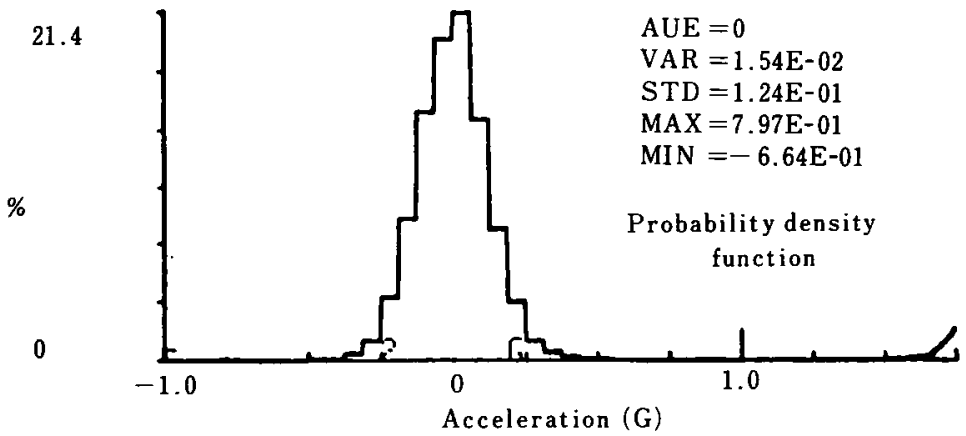

WINDOW

HANNING

COMMENT 3

KITSUKI

TEST-DRIVE

TRUCK

COUNT 1

$\mathrm{DF}=$

9.77E- 02

Fig. 4 Analytical results of vibrating acceleration observed on truck during transportation with the speed of $55 \mathrm{~km} / \mathrm{h}$ on paved roads

を生じた.Fig. 7 及び Fig. 8 は無菌バッグの損傷程 度を目視により判定したすのである，貨車輸送とトラッ ク・フェリー輸送を比較すると，前者の損傷程度の方が 高い，輸送中のクラックの発生率は，緩衛処置を施すこ とによって低减できた，緩衝方式 1 (A 区) ではトラッ ク・フェリー輸送の場合，わずかなクラックやピンホー ルが観察される程度であったが，貨車輸送の場合，8割 のものに何らかのクラックが生じ，また 4 割のものにピ ンホールが生じた．緩衛方式1ではいずれの輸送方式に おいても不十分之思われる. 䌅街処置の中で最す損傷度 の小さかったのは，半円状の発泡スチロール板による緩
衝方式 3（C区）で，いずれの輸送においてあクラック やピンホールは観察されなかった。

内容物の外周的 $10 \mathrm{~cm}$ を倲結させる東結処理も損伤 程度を低隇させる効果があった，その効果は現行の殓衝 方式 4(D区) と同じ程度であった。

\section{4. 賣鹪要因の解明}

貨車輸送とトラック・フェリ一輸送とでは前者におい て多くのクラックが発生した，その原因を，輸送シミュ レーションを応用して考察する.

考察に必要な振動加速度のピーク值の頻度分布, 内容 物の振動特性,ならびに S-N 曲線をそれぞれ Table 

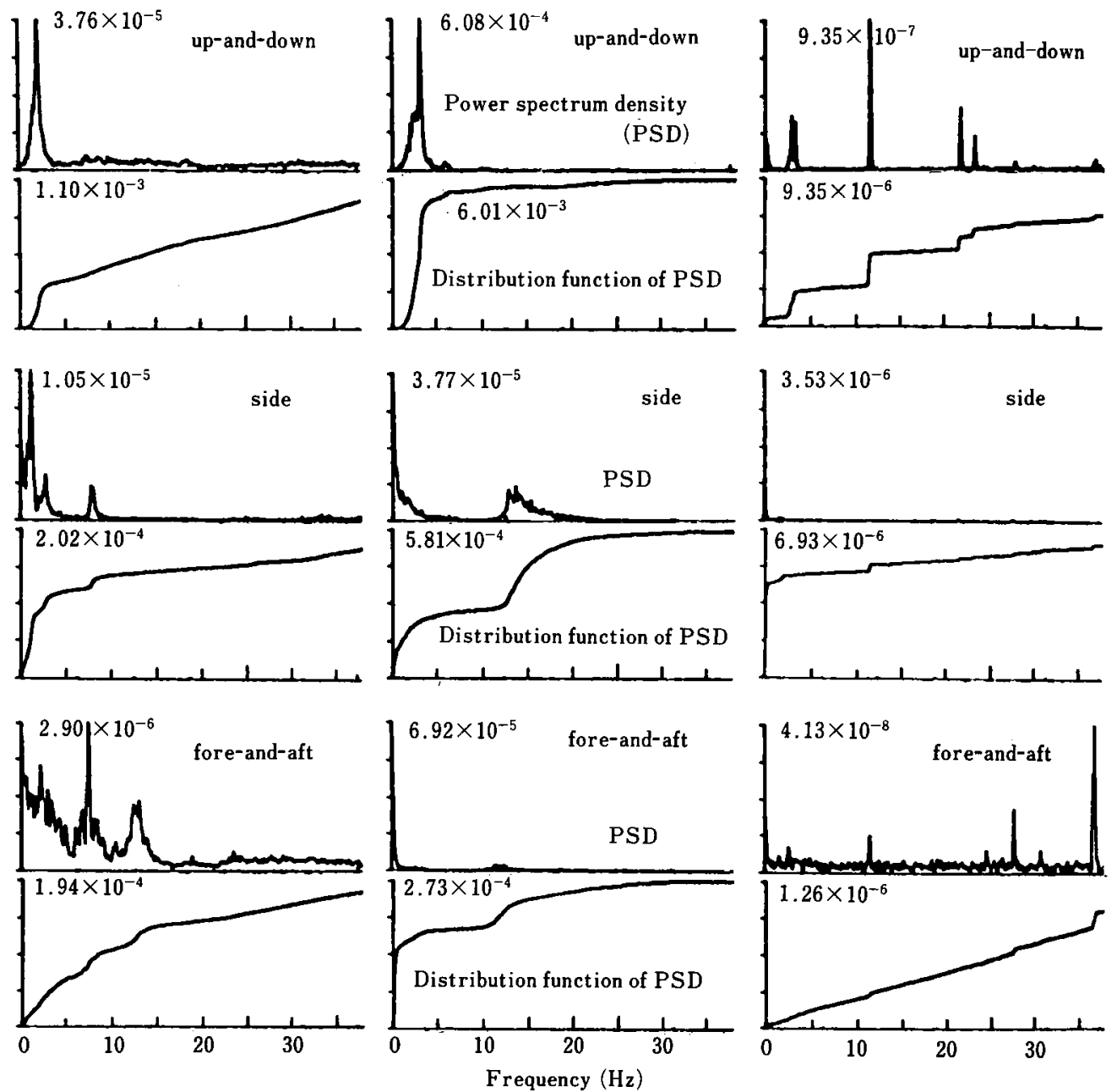

(1) Freight car with the speed of $60 \sim 70 \mathrm{~km} / \mathrm{h}$

(2) Truck with the seed of $60 \mathrm{~km} / \mathrm{h}$ on paved roads
(3) Ferry boat with the speed of 20 knots (about $37 \mathrm{~km} / \mathrm{h}$ )

Fig. 5 Analytical results of vibrating acceleration observed on the freight car, truck and ferry boat used

3, Fig. 9, Fig. 10 に示す.

Table 3は，小型衝撃記録計で記録した全輸送行程の 振動加速度の頻度分布である，上下，左右，前後の振動 とむ貨車輸送よりトラック・フェリー輸送において激し 加た。

Fig. 9 は，振動により動摇する内容物表面における 波動を波の高さで示したもので，上下振動の場合，2.5， $3,3.5,4.25 \mathrm{~Hz}$ に共振点加観察される. 水平振動の場 合は， $1 \mathrm{G}$ 以下の加速度であ横向きの大きな波が発生し，
$1 \mathrm{~Hz}$ 近傍に最大の共振点が存在した。濃縮果汁では共 桭点は低波長側にシフトした。

Fig. 10 は，緩衝処置を施さないドラム缶式無菌バッ グの S-N 曲線で， A は上下振動 $(3 \mathrm{~Hz}$ 用)によって, $\mathrm{B}$ は水平振動（1 Hz 用）によって作成したものである. 無菌バッグの損傷は，振動に伴う同バッグの屈曲による 疲労破壊で，同バッグは水平振動によって破壊されやす いことがわかる，それぞれの S-N 曲線は次式で示され $ろ^{3)}$. 


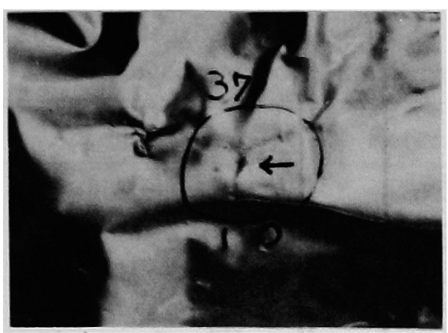

Fig. 6 Injury observed on the surface of the aseptic bag after actual transportation

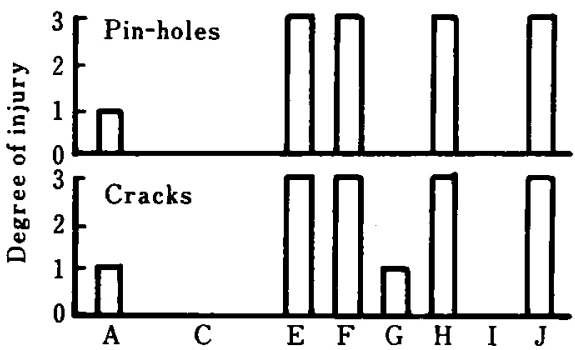

Fig. 7 Degree of injury of the aseptic bag transported by train

$$
\begin{array}{ll}
\text { 上下振動 } & \mathrm{N} \cdot \mathrm{G}^{2.58}=2043 \quad(3 \mathrm{~Hz} \text { 用 }) \\
\text { 水平振動 } & \mathrm{N} \cdot \mathrm{G}^{3.75}=1.331(1 \mathrm{~Hz} \text { 用 })
\end{array}
$$

Table 3 からわかるように，全輸送行程における振 動は，貨車輸送よりトラック・フェリー輸送において激 しかった．また，貨車及びトラックに発生する振動のう ち上下振動について，パワースペクトル密度関数 (Fig. 5）上内容物の振動特性（Fig. 9）を比較すると，以下 のようになる，すなわち，貨車に多く発生する $2 \mathrm{~Hz}$ 近 傍の振動は，内容物の共振点から少しはずれ，内容物を 動摇するに至らないが，トラックの荷台に発生する3 $\mathrm{Hz}$ 近傍の振動は, 内容物の共振点の一つと全く一致し ており，包装された内容物は激しく動摇する．したがっ

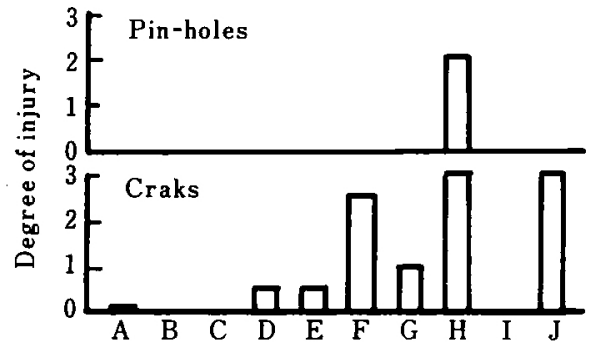

Fig. 8 Degree of injury of the aseptic bag transported by truck and ferry boat

Table 3 Frequency of occurence of vibrating acceleration during $1200 \mathrm{~km}$ transpor-

\begin{tabular}{|c|c|c|c|c|c|c|}
\hline \multirow{2}{*}{$\begin{array}{l}\text { Acceleration } \\
\qquad(G)\end{array}$} & \multicolumn{3}{|c|}{ Truck and ferry boat } & \multicolumn{3}{|c|}{ Train } \\
\hline & up-down & side & fore-aft & up-down & side & fore-aft \\
\hline $0.4 \sim 0.5$ & 628 & 64 & 5 & 349 & 24 & 1 \\
\hline $0.5 \sim 0.6$ & 560 & 28 & 2 & 208 & 9 & 1 \\
\hline $0.6 \sim 0.7$ & 333 & 16 & 0 & 98 & 9 & 0 \\
\hline $0.7 \sim 0.8$ & 209 & 1 & 0 & 46 & 6 & 0 \\
\hline $0.8 \sim 0.9$ & 130 & 2 & 0 & 26 & 4 & 0 \\
\hline $0.9 \sim 1.0$ & 91 & 0 & 0 & 14 & 5 & 0 \\
\hline $1.0 \sim 1.1$ & 47 & 0 & 0 & 21 & 1 & 0 \\
\hline $1.1 \sim 1.2$ & 32 & 1 & 0 & 8 & 1 & 0 \\
\hline $1.2 \sim 1.3$ & 13 & 0 & 0 & 3 & 1 & 0 \\
\hline $1.3 \sim 1.4$ & 8 & 0 & 0 & 6 & 3 & 0 \\
\hline $1.4 \sim 1.5$ & 2 & 0 & 0 & 2 & 0 & 0 \\
\hline $1.5 \sim 1.6$ & 4 & 0 & 0 & 2 & 0 & 0 \\
\hline $1.6 \sim 1.7$ & 1 & 0 & 0 & 0 & 0 & 0 \\
\hline $1.7 \sim 1.8$ & 2 & 0 & 0 & 0 & 0 & 0 \\
\hline
\end{tabular}
tation from Kitsuki to Ebina 


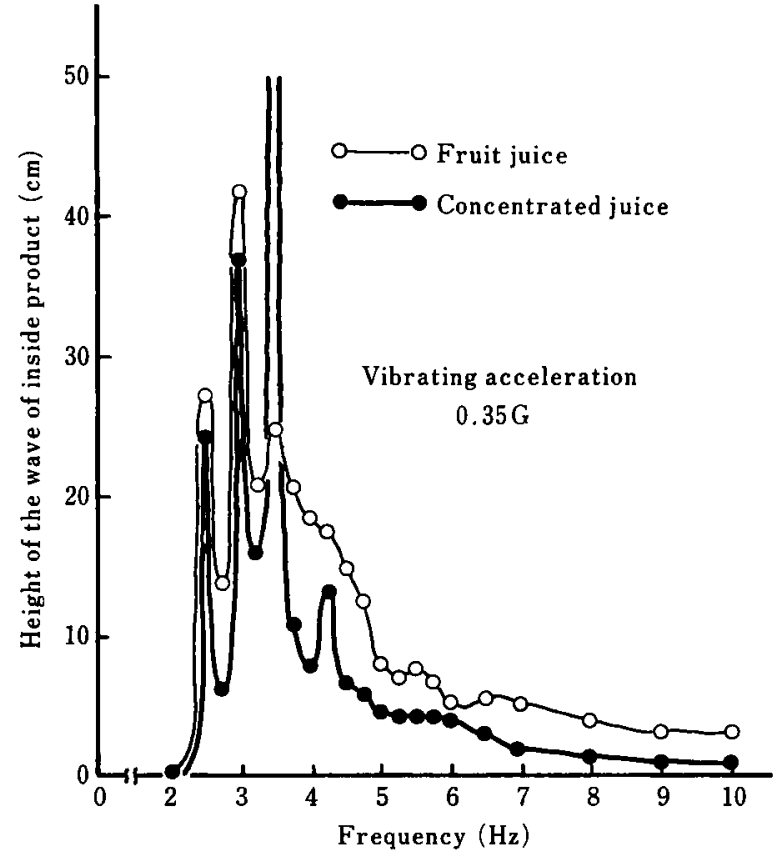

(1) Up-and-down vibration

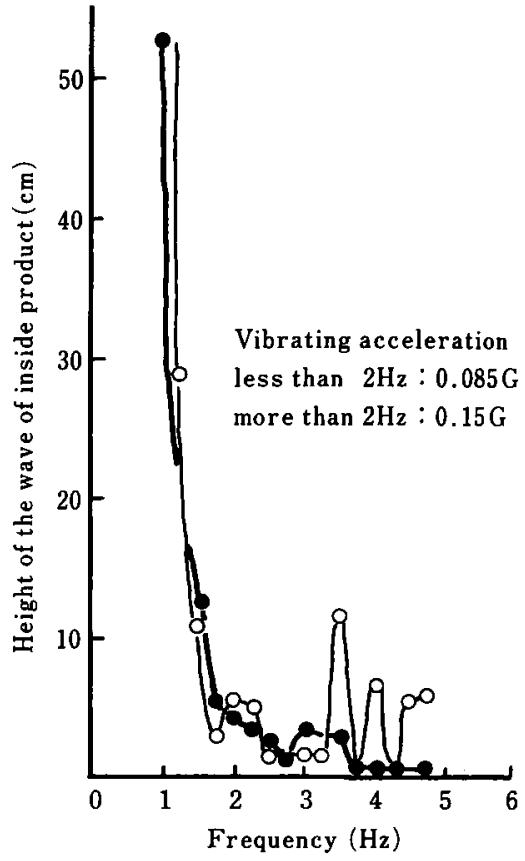

(2) Horizontal vibration

Fig. 9 Vibrating characteristics of the products in the aseptic bag

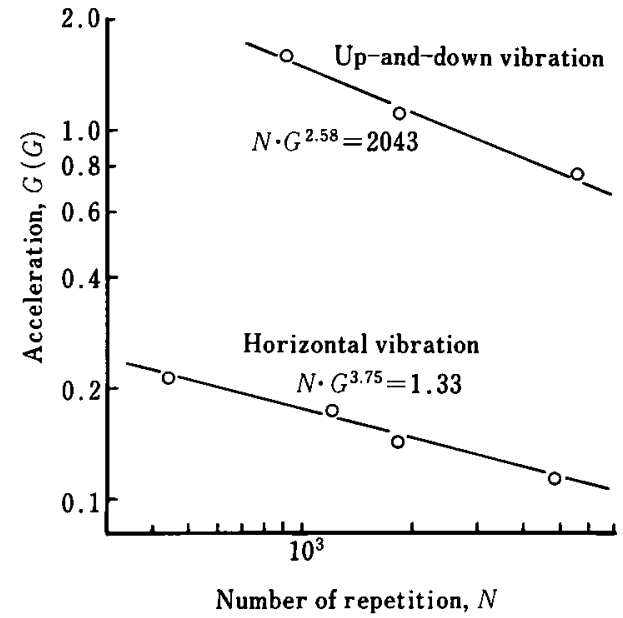

Fig. 10 S-N curve for the aseptic bag used as usual

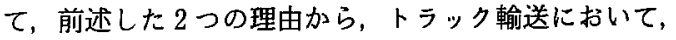
より多くのクラックが生じるはずである. しかし，実際 の輸送では，貨物輸送の損傷が多かった。

ところで, 内容物は, 水平振動の場合, $1 \mathrm{~Hz}$ 近傍に
大きな共振点を有すること及び同条件において無菌バッ グにクラックが生じやすいことを先に述べた. Fig. 5 から明らかなように，水平振動における $1 \mathrm{~Hz}$ 近傍の PSD ピークは, 貨車輸送の左右浱動において存在す る.したがって，貨車輸送においては，左右振動が内容 物の水平振動と共振しドラム缶内に大きな動摇が起こり， それによって無菌バッグにクラックが多く発生すると考 えられる.

そこで，以上述べた考察にもとづき，貨車及びトラッ ク・フェリー輸送した試料の損傷度をPLAMGRENMINER の線形損傷蓄積の法則 ${ }^{4)}$ により推定する. 加速 度振幅 $G_{i}$ が $n_{i}$ 回作用する産物の損傷度は, 次式より 算出できる3.

$$
D=\frac{1}{\beta} \sum_{i} n_{i} \cdot G_{i}{ }^{a}
$$

ここで, $\alpha, \beta$ は産物固有の值で, $\mathrm{S}-\mathrm{N}$ 曲線から求め られる值である.

$60 \mathrm{~km} / \mathrm{h}$ で走行中の貨車の左右振動によって生じる 損傷の推定の例を Table 4 に示す. 表中のピーク值の 頻度分布は電気的に測定した加速度信号からリアルタイ ム信号解析装置を用いて解析したもので，解析時の条件 
Table 4 Degree of damage of the bag estimated from S-N curve and frequency of occurence of side vibrating acceleration of the train

\begin{tabular}{ccccc}
\hline Acceleration $(G)$ & Percentage $(\%)$ & $n_{i}$ & $N_{i}$ & $n_{i} / N_{i}$ \\
\hline $0 \times 10^{-2} \sim 1.5 \times 10^{-2}$ & 57.5 & $3.13 \times 10^{5}$ & $1.24 \times 10^{8}$ & $2.52 \times 10^{-3}$ \\
$1.6 \times 10^{-2} \sim 3.0 \times 10^{-2}$ & 29.8 & $1.62 \times 10^{5}$ & $1.85 \times 10^{6}$ & $8.76 \times 10^{-2}$ \\
$3.1 \times 10^{-2} \sim 4.6 \times 10^{-2}$ & 8.91 & $4.85 \times 10^{4}$ & $2.68 \times 10^{5}$ & $1.81 \times 10^{-1}$ \\
$4.7 \times 10^{-2} \sim 6.1 \times 10^{-2}$ & 2.54 & $1.38 \times 10^{4}$ & $7.54 \times 10^{4}$ & $1.83 \times 10^{-1}$ \\
$6.3 \times 10^{-2} \sim 7.7 \times 10^{-2}$ & 0.700 & $3.81 \times 10^{3}$ & $2.85 \times 10^{4}$ & $1.34 \times 10^{-1}$ \\
$7.8 \times 10^{-2} \sim 9.3 \times 10^{-2}$ & 0.217 & $1.18 \times 10^{3}$ & $1.35 \times 10^{4}$ & $8.74 \times 10^{-2}$ \\
$9.4 \times 10^{-2} \sim 1.1 \times 10^{-1}$ & 0.193 & $1.05 \times 10^{3}$ & $6.94 \times 10^{3}$ & $1.51 \times 10^{-1}$ \\
$1.1 \times 10^{-1} \sim 1.4 \times 10^{-1}$ & 0.0241 & $1.31 \times 10^{2}$ & $3.24 \times 10^{3}$ & $4.04 \times 10^{-2}$ \\
$1.4 \times 10^{-1} \sim 1.6 \times 10^{-1}$ & 0.0483 & $2.63 \times 10^{2}$ & $1.63 \times 10^{3}$ & $1.61 \times 10^{-1}$ \\
\hline Degree of damage & & & & 1.03 \\
\hline
\end{tabular}

Table 5 Estimated degree of damage of the bag after $1200 \mathrm{~km}$ transportation

\begin{tabular}{llccc}
\hline & $\begin{array}{l}\text { Directions of } \\
\text { vibration }\end{array}$ & $\begin{array}{l}\text { Degree of } \\
\text { damage }\end{array}$ & $\begin{array}{l}\text { Total degree } \\
\text { of damage }\end{array}$ & Nishioita-Tokyo \\
Train & Up-and-down & 0.28 & 1.31 & Osaka-Okazaki \\
\hline $\begin{array}{l}\text { Truck } \\
\text { and } \\
\text { ferry boat }\end{array}$ & Side & 1.03 & 0.79 & Okazaki-Ebina \\
\hline
\end{tabular}

は, サンプリング時間間隔 $10 \mathrm{ms,} \mathrm{ブロックサイズ} \mathrm{1024,}$ 平均回数 50 回であった. それぞれの加速度振幅におけ る $n_{i}$ は輸送中に生じる全ピークの回数にピークの発生 する頻度割合を乗じて求め, 許容回数 $N_{i}$ は $\mathrm{S}-\mathrm{N}$ 曲線 から求めた。（2）式を用いて算出した結果, 貨車の左右 振動によって生じる損傷度は 1.03 となった。 以下，同 様な計算を行った結果を Table 5 に示す．貨車輸送の 場合の損傷度は上下振動，左右振動によるそれぞれの損 傷度を合計して 1.31, トラック・フェリ一輸送の場合 の損傷度は国道，高速走行中の損傷度を合計して 0.79 となった．損傷度 1 の時対象物は損傷に至ることから， 以上の考察は実際の輸送試験の結果と一致した。

\section{要 約}

果汁,トマトピューレなどの液状食品の保存及び輸送 容器として用いられつつあるドラム缶式無菌バッグの耐 振動衝撃性について解明するとともに，ドラム缶内無菌 バッグのクラックやピンホールの防止策について検討し，
次の結果を得た.

（1）ドラム缶式無菌バッグは，大分県杵築市から神奈 川県海老名市までの $1200 \mathrm{~km}$ の輸送中にクラックを生 じ，著しい場合にはピンホールを生じた．損傷程度はト ラック・フェリー輸送より貨車輸送において著しかっ た.

(2) 無菌バッグの損傷は輸送中の振動に伴って生じる 同バッグの届曲現象による疲労破壊で，上下振動より水 平振動によって生じやすかった。

(3) クラックの発生率は，緩衝処置を施すことによっ て低減でき，特に半円状の発泡スチロール板を用いた緩 衝方式 3（C区）で緩衝効果が最す高かった。この場合， $1200 \mathrm{~km}$ 以上の貨輸送及びトラック・フェリー輸送 の両輸送区においてもクラックヤピンホールは発生しな かった。

(4) トラック・フェリー輸送より貨車輸送において多 く損傷が発生する現象は貨車の水平振動がドラム缶の内 容物の水平振動と共振を起こすことが原因であった。 


文献

1）日本果汁協会監修：果汁・果実飲料事典，p. 436, (朝倉, 東京) (1978).

2）早川 昭・岩元睦夫 - 河野澄夫・木村 進 : 食総 研報，40，89（1982）。
3）岩元睦大 ·河野澄夫・早川 昭：農機誌， 40 (1), 61 (1978).

4）河本 寛ほか：金属の疲れと設計，p. 141，(コ 口ナ社, 東京) (1974).

（昭和 63 年 6 月 14 日受理）

\section{新刊 紹介}

Food Structure : Its Creation and Evaluation

J.R. Mitchell and J.M.V. Blanshard 編

食品構造の解明は，新食品の開発や既存食品の改良に 久くことの出来ないものとして注目を集めている. 本書 は第 44 回 Nottingham Ester School in Agricultural Science のプロシーディングである. 内容は 26 節からなり, 各種のゲル, エマルジョン, 泡の構造や安 定性など食品構造の基本的概念について論じたあのから， 蛋白質の紡糸による織維化やエクストルージョンによる 組織化，再構成肉やすり身を原料にした練り製品の製造， 穀類のエクストルージョン処理，脂肪や糖の結晶構造な どと組織の関保を論じたもの, 光学顕微鏡や電子顕微鏡 による食品の構造評価や食品の物理的性質の測定法につ いて論じたものなど多岐にわたっている，食品の構造に 関する最新の情報が集めら机ている.

$16 \times 23 \mathrm{~cm}, 504$ 頁, 1988 年版, 75 ポンド

Butterworth Scientific Ltd.

Westbury House, Bury Street, Guildford

GU 25 BH, England 